\title{
Tinjauan Fatwa DSN MUI Nomor 19 Tahun 2001 Terhadap Implementasi Pembiayaan Qard di Bank Wakaf Mikro Al Fitrah Mava Mandiri Surabaya
}

\author{
Lian Fuad \\ UIN Sunan Ampel Surabaya \\ cakyan85@gmail.com \\ Rohmah \\ UIN Sunan Ampel Surabaya \\ rohmahhofi11@gmail.com
}

\begin{abstract}
Abstrak
Penelitian ini bermaksud untuk menganalisis implementasi pembiayaan qard yang diterapkan di bank wakaf mikro al-Fitrah Wava Mandiri Surabaya dikaitkan dengan fatwa MUI nomor 19 tahun 2001. Letak signifikansi penelitian ini berada pada kajian relevansi praktik qard pada lembaga wakaf tersebut dan praktik yang diterapkan untuk memanfaatkan atau mengembangkan wakaf produktif menjadi aset wakaf yang bermanfaat untuk masyarakat. Kajian ini penting dilakukan mengingat banyaknya lembaga wakaf yang kesulitan menjalankan akad qard dalam rangka mengembangkan aset yang ada. Untuk mendapatkan hasil penelitian yang sistematis, penelitian ini didekati secara kualitatif deskriptif. Pengumpulan data dilakukan melalui wawancara dengan informan yaitu manager, asisten manager, administrasi dan nasabah Bank Wakaf Mikro Al Fitrah Wava Mandiri Surabaya. Maka ditemukan beberapa hal penting, yaitu implementasi pembiayaan qard dalam mengembangkan usaha mikro di Bank Wakaf Mikro Al Fitrah Wava Mandiri sesuai dengan Fatwa Dewan Syariah Nasional No: 19/DSN-MUI/IV/2001. Proses pembiayaan qard melalui 3 tahapan diantaranya Pra PWK (Pelatihan Wajib Kelompok), PWK dan UPK (Ujian Pengesahan Kelompok). Pelatihan wajib diikuti oleh calon nasabah sebelum melakukan proses pembiayaan di Bank Wakaf Mikro Al Fitrah Wava Mandiri Surabaya. Hal tersebut bertujuan agar calon nasabah mengetahui akan program-program Bank Wakaf Mikro. Proses pembiayaan qard menggunakan pola 2-2-1 dan tanggung renteng. Pola $2-2-1$ berfungsi untuk mengutamakan nasabah yang membutuhkan dana. Tanggung renteng digunakan apabila nasabah tidak mengikuti pertemuan mingguan maka semua angsuran ditanggung oleh kelompok. Pembiayaan yang diberikan Bank Wakaf Mikro Al Fitrah Wava Mandiri Surabaya tanpa agunan, sehingga pinjaman dana yang diberikan sangat kecil. Implementasi pembiayaan qard terlaksana dengan baik sehingga berdampak baik terhadap pengembangan usaha mikro.
\end{abstract}

Keyword: Fatwa DSN MUI No 19 Tahun 2001, Pembiayaan Qard 


\section{Latar Belakang}

Indonesia merupakan negara yang berkembang, namun dilihat dari segi perekonomiannya, Indonesia masih krisis. Hal ini dapat dibuktikan dengan tingginya jumlah penduduk miskin dan pengangguran. Fenomena tidak baik ini menjadi problem yang dapat mengganggu stabilitas dan henmonisasi sosial. Maka dari itu, salah satu upaya yang harus dilakukan untuk meningkatkan kesejahteraan ekonomi masyarakat adalah memaksimalkan potensi kelembagaan yang mengatur tentang zakat, infaq, shodaqah dan wakaf.

Lembaga ekonomi yang ditawarkan oleh Islam merupakan upayaupaya strategis dalam rangka mengatasi berbagai problematika kehidupan masyarakat. ${ }^{1}$ Untuk mengatasi masalah-masalah sosial, wakaf merupakan sumber dana yang cukup pontensial. Selama ini, program pengentasan masyarakat dari kemiskinan bergantung dari bantuan kredit dari luar negeri, terutama dari Bank Dunia. Tapi dana tersebut terbatas dari segi jumlah dan waktu. ${ }^{2}$ Pemberdayaan wakaf di Indonesia masih cendurung pada kegiatankegiatan ibadah.Hal ini disebabkan karena keterbatasan pemahanan umat Islam mengenai wakaf, baik harta benda yang diwakafkan, mauquf 'alaih maupun nazhir.

Wakaf menurut UU No. 41 tahun 2014 adalah perbuatan hukum wakif untuk memisahkan dan/atau menyerahkan sebagian harta benda miliknya untuk dimanfaatkan selamanya atau untuk jangka waktu tertentu sesuai dengan kepentingannya guna keperluan ibadah dan/atau kesejahteraan umum menurut syariah. Demikian pula wakaf juga merupakan suatu pengabdian diri kepada Allah Swt, sebagai jembatan antara hubungn sesama manusia dengan pencipta-Nya.selain itu wakaf berfungsi untuk rasa sosial sesama umat.

Dengan pesatnya perkembangan zaman, wakaf tidak hanya diasosasikan pada obyek wakaf berupa tanah, ${ }^{3}$ akan tetapi sudah merambah kepada wakaf bentuk lain. Penjelasan tentang hal tersebut sudah ada dengan diterbitkannya Peraturan Pemerintah No.28 tahun 1977 dan kemudian

1Depag RI, Pedoman Pengelolaan dan Pengembangan Wakaf, (Jakarta: Ditjen Bimas Islam dan Penyelenggara Haji Proyek Peningkatan Pemberdayaan Wakaf,2004),h.73.

2 Depag RI, Strategi Pengembangan Wakaf Tunai di Indonesia, (Jakarta: Direktor Pemberdayaan Wakaf,2007),h. 34

${ }^{3}$ Data terakhir per 23 Juli 2009, tanah wakaf di Indonesia berjumlah 2.719.854.759,72 $\mathrm{m}^{2}$ yang tersebar di 451.305 lokasi (Dokumen dari Departemen Agama,2009) 
peraturan tersebut diperbaharui dengan diterbitkannya UU No.41 tahun 2004. Perbedaan dari kedua peraturan tersebut dalam aspek pengelolaan harta wakaf dan barang yang diwakafkan.Dalam PP No. 28 tahun 1977 harta wakaf yang diwakafkan hanya berbentuk barang tidak bergerak misalnya tanah, masjid, jembatan dan madrasah untuk kepentingan sosial. Sedangkan dalam UU No. 41 tahun 2004 mengembangkan dari benda yang diwakafkan, bentuk benda yang diwakafkan bukan hanya benda yang tidak bergerak saja melainkan benda yang bergerakpun bisa diwakafkan. Benda wakaf yang bisa bergerak misalnya uang sehingga nilai dari uang yang diwakafkan bisa dikembangkan melalui investasi produktif untuk pembangunan nasional dalam kesejahterahkan masyarkat.

Benda wakaf dapat diartikan pula seperti mewakafkan harta benda wakaf yang berupa benda bergerak atau tidak bergerak. Harta benda wakaf bisa dikelola oleh lembaga baik perbankan maupun non perbankan. Keuntungan dari harta benda wakaf bisa disalurkan kepada mauquf 'alaih. Selain itu dana wakaf bisa dikelola dengan cara produktif, dana wakaf juga bisa diinvestasikan oleh nazhir. Sedangkan wakaf produktif adalah harta benda yang dikelola olehnazhir yang dikembangkan dengan cara-cara tertentu dan bisa menghasilkan kemanfaatan bagi mauquf 'alaih.

Adapun salah satu contoh lembaga keuangan mikro berpola syariah (LKM Syariah) yang mengelola wakaf produktif ialah Bank Wakaf Mikro (BWM) yang didirikan atas izin Otoritas Jasa Keuangan (OJK) yang berbadan hukum Koperasi. Dalam program ini dana hasil dari pengelola wakaf oleh nazhir (LAZNAS BMS Umat) diserahkan kepada LKM Syariah sebagai mauquf 'alaih yang kemudian digunakan untuk mendukung pemberdayaan usaha-usaha mikro masyarakat miskin di sekitar Pesantren. ${ }^{4}$ Kegiatan Bank Wakaf Mikro melakukan permodalan atau pembiayaan kepada mayarakat kecil. Dengan cara pelatihan dan pendampingan, agar usaha para nasabah bisa berkembang dan produktif. ${ }^{5}$ Pembiayaan Bank Wakaf Mikro sama halnya seperti Bank Syariah. Hal ini yang membedakan ketika awal transaksi pembiayaan yang digunakan akad qard.

Disinilah letak signifikansi yang harus diteliti. Pembiayaan qord yang diterapkan oleh lembaga wakaf tersebut berorientasi pada wujud

${ }^{4}$ Kebijakan Manajemen Organisasi LKM Syariah Bank Wakaf Mikro, 2018.

${ }^{5}$ Www.ojk.go.id/id/berita-dan-kegiatan/info-terkini/Pages/Infografis-Bank-Wakaf-MikroMendorong-Ekonomi-Umat.aspx. Diakses pada 18 Oktober 2018. 
menciptakan perekonomian yang mapan dan mengurangi kemiskinan melalui usaha. Terobosan ini termasuk langka dilakukan di Indonesia, sebab sedikit sekali lembaga wakaf yang mampu mengelola asetnya. Maka disinilah letak pentingnya penelitian ini dilakukan.

\section{Kerangka Teoritis}

\section{Konsep Qard}

Al- qard adalah pemberian harta kepada orang lain yang dapat ditagih atau diminta kembali atau dengan kata lain meminjamkan tanpa mengharapakan imbalan. Dalam literatur fiqih klasik, qard dikategorikan dalam aqd tatawwui atau akad saling membantu dan bukan transaksi komersial. ${ }^{6}$ Rukun qard ada tiga, yaitu: (1) S\}ighat adalah ijab dan Kabul,(2)'Aqidain adalah (dua pihak yang melakukan transaksi) adalah pemberi utang dan pengutang, dan (3) Harta yang diutangkan, rukun harta yang diutangkan adalah sebagai berikut: 1) harta berupa harta yang ada padanya, maksudnya harta yang satu sama lain dalam jneis yang sama tidak banyak berbeda yang mengakibatkan perbedaan nilai, seperti uang, barangbarang yang dapat ditakar, ditimbang, ditanam dan dihitung. 2) harta yang diutangkan berupa benda bukan mengutangkan manfaatnya. 3) harta yang diutangkan diketahui, yaitu diketahui kadarnya dan diketahui sifatnya.

Adapun syarat sahnya Al-qard antara lain: (1) Qard atau barang yang dipinjamkan harus barang yang memiliki manfaat, tidak sah jika tidak ada kemungkinan pemanfaatan, karena qard adalah akad terhadap harta, (2) akad qard tidak bisa dilaksanakan kecuali dengan ijab dan kabul, seperti halnya dalam jual beli, dan (3) bagi pengutang harus merdeka,balig, berakal sehat dan pandai (rasyid, dapat membedakan baik dan buruk). ${ }^{7}$

\section{Fatwa DSN MUI No 19 Tahun 2001}

Fatwa DSNMUI No 19 Tahun $2001^{8}$ ini menjelaskan mengenai al - qard adalah suatu akad pinjaman kepada nasabah dengan ketentuan bahwa

\footnotetext{
6 Ahmad asy-Syarbasyi, al-Mu'jam al-Iqtisad al-Islami (Beirut: Dar Alamil Kutub, 1987): Sayyid Sabiq, Fiqhus Sunnah (Beirut: Darul-Kitab al-Arabi, 1987), cetakan ke-8, vol. III, h.163.

${ }^{7}$ Mardani, Figh Ekonomi Islam, h.335

${ }^{8}$ Fatwa DSN MUI No 19 Tahun 2001
} 
nasabah wajib mengembalikan dan ayang diterimanya kepada LKS pada waktu yang telah disepakati oleh LKS dan nasabah.

Dalam Fatwa DSN No 19 tersebut terdapat beberapa ketentuan di bolehkannya dilakukan akad al - qard yaitu : (1) Al - qard adalah pinjaman yang diberikan kepada nasabah (muqtarid\{) yang memerlukan, (2) nasabah al - gard wajib mengembalikan jumlah pokok yang diterima pada waktu yang telah disepakati bersama, (3) biaya administrasi dibebankan kepada nasabah, (4) LKS dapat meminta jaminan kepada nasabah bilamana dipandang perlu, (5) nasabah al - qard dapat memberikan tambahan (sumbangan) dengan sukarela kepada LKS selama tidak diperjanjikan dalam akad, (6) jika nasabah tidak mengembalikan sebagian atau seluruh kewajiban pada saat yang telah disepakati dan LKS telah memastikan ketidakmampuanya, LKS dapat: memperpanjang jangka waktu pengembalian, atau menghapus (write off) sebagian atau seluruh kewajibannya, (7) dalam hal nasabah tidak menunjukkan keinginan mengembalikan sebagian atau seluruh kewajibannya dan bukan karena ketidak-mampuannya, LKS dapat menjatuhkan sanksi kepada nasabah (8) sanksi yang dijatuhkan kepada nasabah sebagaimana dimaksud dapat berupa dan tidak terbatas pada penjualan barang jaminan, (9) jika barang jaminan tidak mencukupi, nasabah tetap harus memenuhi kewajibannya secara penuh, (10)jika salah satu pihak tidak menunaikan kewajibannya atau jika terjadi perselisihan di antara para pihak, maka penyelesaiannya dilakukan melalui Badan Artitrasi Syari'ah setelah tidak tercapai kesepakatan melalui musyawarah, dan (11) fatwa ini berlaku sejak tanggal ditetapkan dengan ketentuan jika di kemudian hari ternyata terdapat kekeliruan, akan diubah dan disempurnakan sebagaimana mestinya.

\section{Metode Penelitian}

Penelitian ini menggunkan metode deskriptif analitik kualitatif. Metode ini berfungsi untuk mendeskripsikan dan menganalisis terhadap objek yang diteliti melalui data-data yang terkumpul sehingga memberikan kesimpulan secara umum.

Data yang dikumpulkan berupa data primer dan data sekunder. Data primer yang dikumpulkan dalam penelitian ini adalah: Implementasi pembiayaan qard di Bank Wakaf Mikro Al Fitrah Wava Mandiri Surabaya, model pembiayaan qard di Bank Wakaf Mikro Al- Fitrah Wava Mandiri 
Surabaya dan prosedur pembiayaan awal yang digunakan oleh Bank Wakaf MikroAl- Fitrah Wava Mandiri Surabaya. Data sekunder yang dikumpulkan dalam penelitian ini adalah teori-teori tentang pembiayaan yang berasal dari jurnal, artikel, buku dan skripsi terdahulu.

Sumber data yang digunakan adalah sumber primer dan sumber data sekunder. Sumber primer adalah sebuah sumber utama yang digunakan dalam penelitian sebagai bahan utama pada penelitian ini. ${ }^{9}$ Sumber dalam penelitian ini melalui Manager (pimpinan), Asisten Manager, nasabah dan karyawan Bank Wakaf Mikro Al Fitrah Wava Mandiri Surabaya.Sumber sekunder adalah sebuah sumber data sebagai pendukung pada penelitian guna sebagai pelengkap pada sumber data primer. ${ }^{10}$ Sumber sekunder pada penelitian ini adalah dokumen mengenai pembiayaan dan buku yang berhubungan dengan penelitian ini.

Proses pengumpulan data melalui observasi, wawancara dan dokumentasi. Observasi dalam penelitian ini digunakan untuk memperoleh informasi berkaitan dengan keadaan lokasi dan kondisi Bank Wakaf Mikro Al Fitrah Wava Mandiri Surabaya. Pada penelitian ini observasi dilakukan secara langsung ke lapangan untuk mengamati dan mengikuti kegiatan yang berhubungan dengan implementasi pembiayaan qard.Dengan hal tersebut dapat mengetahui proses pembiayaan qard, prosedur dalam pengajuan pembiayaan qard, kriteria nasabah dan pelatihan yang diberikan oleh Bank Wakaf Mikro.Wawancara adalah percakapan tatap muka dengan dua orang antara narasumber dengan pewawancara melalui tanya jawab. Narasumber dalam penelitian ini adalah Manager (pimpinan), Manager Asisten, nasabah dan karyawan Bank Wakaf Mikro Al Fitrah Wava Mandiri Surabaya.Dokumen dalam penelitian ini berupa buku angsuran pembiayaan qard, formulir pendaftaran nasabah, surat perjanjian, materi selama Pra PWK, PWK dan UPK yang diterbitkan oleh Bank Wakaf Mikro Al Fitrah Wava Mandiri Surabaya.

\footnotetext{
${ }_{9}^{9}$ Burhan Bungin, Metodologi Penelitian Sosial Format-Format Kuantitaf dan Kualitatif, (Surabaya: Airlangga University press, 2001), h. 129.

${ }^{10}$ Ibid.
} 


\section{Hasil Penelitian}

\section{Analisis Implementasi Pembiayaan Qard}

Bank Wakaf Mikro Al Fitrah Wava Mandiri Surabaya salah satu lembaga keuangan yang menerapkan pembiayaan qard. Pembiayaan qard di Bank Wakaf Mikro Al Fitrah Wava Mandiri Surabaya menggunakan dasar hukum Fatwa DSN No: 19/DSN-MUI/IV/2001yaitu mengenai al - qard. "Produk pembiayaan qard di Bank Wakaf Mikro Al Fitrah Wava Mandiri Surabaya dalam pengaplikasian diterapkan seperti al- qard dengan mengacu pada Fatwa DSN No: 19/DSN-MUI/IV/2001". ${ }^{11}$ Dalam wawancara dengan Bapak Suroso selaku manager dari Bank Wakaf Mikro Al Fitrah Wava Mandiri Surabaya mengatakan bahwasanya pembiayaan qard mengacu pada Fatwa DSN No: 19/DSN-MUI/IV/2001.

Kategori nasabah yang bisa menerima pembiayaan qard adalah anggota yang mempunyai usaha, baik dalam skala kecil tetapi mempunyai kemauan untuk mengembangkan usahanya. Hal ini sesuai dengan teori Ismail ${ }^{12}$, bahwa dalam pembiayaan qard digunakan untuk memberikan pinjaman kepada pedagang kecil untuk membantu nasabah dalam meningkatkan penjualannya baik dari bahan baku ataupun peralatan yang lain.

Dana pembiayaan qard yang diberikan kepada nasabah telah ditentukan oleh Bank Wakaf Mikro Al Fitrah Wava Mandiri Surabaya. Besar nominal pinjaman yang diberikan untuk akad qard sebesar Rp. 1000.000 sampai 1.500.000, sesuai dengan syarat dan ketentuan yang berlaku. Untuk pengajuan awal pinjaman yang diberikan sebesar Rp. 1000.000 dengan angsuran Rp. 25.000/minggu dalam 40 kali HALMI. Jasa konsultasi sebesar 3\% dalam 1 tahun, apabila diangsur setiap pertemuan sebesar Rp.700 tapi dibulatkan Rp. 1000 sesuai dengan kesepakatan nasabah. Dana sosial yang digunakan untuk keperluan anggota dan sumbangan kepada masyarakat yang terkena bencana atau panti asuhan, para nasabah membayar infaq dan kas sesuai dengan kesepakatan bersama sebesar Rp. 2000. Apabila pinjaman awal lunas, maka nasabah boleh melakukan proses pembiayaan lagi dengan nominal Rp.1.500.000. Besar anggusran sejumlah Rp. 37.500, selama 40 kali HALMI. Namun ada sebagian kelompok yang mengangsur dalam 20 kali HALMI, hal ini bisa disetujui oleh pihak Bank Wakaf Mikro Al Fitrah Wava

\footnotetext{
${ }^{11}$ Suroso, Manager ,Wawancara, Surabaya, 10 Desember 2018. ${ }^{12}$ Ismali, Perbankan Syariah, h. 219.
} 
Mandiri Surabaya, asalkan nasabah sanggup untuk melunasi pinajamannya. Tetapi hal ini sesuai dengan kesepakatan para nasabah dalam 1 kelompok.

Bank Wakaf Mikro Al Fitrah Wava Mandiri Surabaya dalam persyaratan untuk melakukan pembiayaan qard adalah nasabah harus membentuk kelompok yang terdiri dari 5 anggota. Berikutnya mengikuti Pra PWK (Pelatihan Wajib Kelompok) dan PWK selam 4 hari. Di hari kelima para calon nasabah mengikuti UPK (Ujian Pengesahan Kelompok) sesuai materi yang diberikan disaat PWK. Persyaratan tersebut wajib dipenuhi oleh calon nasabah dalam proses pembiayaan qarddi Bank Wakaf Mikro Al Fitrah Wava Mandiri Surabaya.

Proses pencairan pengajuan pembiayaan qard di Bank Wakaf Mikro Al Fitrah Wava Mandiri Surabaya menggunakan pola 2 - 2 - 1. Pola 2 - 2 - 1 adalah suatu proses pengajuan lebih mengutamakan nasabah yang sangat membutuhkan dana. Setiap 1 kelompok terdiri dari 5 anggota, maka yang pertama melakukan proses pengajuan adalah nasabah di baris kedua dari belakang. Nasabah yang lainnya dilanjutkan pada HALMI berikutnya, tetapi nasabah yang telah cair diawal untuk angsurannya bisa dimulai pada pertemuan HALMI.

Proses berikutnya muqtarid\{ mengikuti program HALMI yang telah ditentukan oleh Bank Wakaf Mikro Al Fitrah Wava Mandiri Surabaya, namun untuk tempat dan waktu pertemuan ditentukan oleh nasabah. Proses pembiayaan qard menggunakan pola tanggung rentang. Tanggung renteng merupakan semua ditanggung bersama dalam sekelompok karena hal ini untuk saling membantu dan memperkuat tali persaudaraan antar nasabah.

\section{Analisis Tinjauan Fatwa DSN MUI No 19 Tahun 2001}

Dewan Syariah Nasional (DSN) adalah lembaga yang dibentuk oleh Mejelis Ulama Indonesia (MUI) yang mempunyai fungsi melaksanakan tugas-tugas MUI dalam menangani masalah yang berhubungan dengan aktifitas lembaga keuangan syariah. Salah satu tugas pokok Dewan Syariah Nasional adalah mengkaji, menggali dan merumuskan nilai dan prinsipprinsip hukum Islam (syari'ah) dalam bentuk fatwa untuk dijadikan pedoman dalam kegiatan transaksi di lembaga keuangan syari'ah melalui Dewan Pengawas Syari'ah melakukan pengawasan terhadap penerapan 
prinsip syariah. ${ }^{13}$

Fatwa DSN MUI mengeluarkan banyak produk yang telah ditetapkan berdasarkan Hukum Islam, salah satunya adalah mengenai Al - Qard. Dewan Syariah Nasional-Majelis Ulama Indonesia telah menetapkan bahwa $A l$ - Qard dalam bisnis semakin berkembang, sehingga diperlukan kejelasan hukumnya dari segi shari'ah. ${ }^{14}$ Seperti Bank Wakaf Mikro Al Fitrah Wava Mandiri Surabaya pembiayaan al - qard yang menggunakan Fatwa DSN MUI No 19 Tahun 2001.

Adapun dampak baik dari dari pembiayaan qard melalui beberapa indikator diantaranya: (1) Peningkatan pendapatan. Program Bank Wakaf Mikro memberikan kontribusi kepada masyarakat sekitar, dengan adanya pembiayaan qard masyarakat dapat meminimalisir margin yang dikeluarkan, (2) Peningkatan usaha. Pembinaan dan pelatihan yang diberikan Bank Wakaf Mikro Al Fitrah Wava Mandiri melalui pembiayaan qard, dampaknya masyarakat dapat meningkatkan usahanya. Hal ini karena adanya inovasi dan kreasi dari nasabah, sehingga jumlah dagangan yang terjual semakin bertambah.Segi pemasarannya pun bisa di akses melalui media sosial, yang mana pada awalnya nasabah masih gaptek mengenai hal tersebut.

Adapun kendala yang dihadapi nasabah dalam pengembangan usaha melalui pembiayaan gard adalah pinjaman yang diberikan Bank Wakaf Mikro Al Fitrah Wava Mandiri Surabaya sangat kecil. Sedangkan pihak Bank Wakaf Mikro Al Fitrah Wava Mandiri Surabaya hanya sanggup memberikan pembiayaan qard sebesar Rp. 1.000 .000 sampai Rp.1.500.000, karena apabila melebihi dari nominal tersebut akad yang digunakan bukan qard lagi melainkan akad yang lain dan marginnya pun berbeda. Bank Wakaf Mikro Al Fitrah sangat berhati-hati dalam pembiayaan qard ini, karena pembiayaan yang diberikan kepada nasabah tanpa agunan. Resiko yang ditanggungpun sangat besar, apabila terjadi sesuatu diluar dugaan.

\section{Kesimpulan}

Impelementasi pembiayaan qard di Bank Wakaf Mikro Al Fitrah Wava Mandiri Surabaya yaitu nasabah membentuk kelompok yang terdiri dari 5

\footnotetext{
${ }^{13}$ Ascarya, Akad \& Produk Bank Syariah (Jakarta : PT.RajaGrafindo Persada, 2008), h. 206

${ }^{14}$ Dewan Syariah Nasional- Majelis Ulama Indonesia, National Sharia Board - Indonesian Council of Ulama( Jakarta : Fatwa DSN MUI, 2014) h.1.
} 
anggota setiap kelompoknya. Prosedur pembiayaan qard melalui 3 tahap diantaranya Pra PWK (Pelatihan Wajib Kelompok), PWK dan UPK (Ujian Pengesahan Kelompok). Proses ini berjalan selama 5 hari, di hari keenam dilanjut dengan proses pengajuan pembiayaan qard. Proses pembiayaan qard menggunakan pola 2-2 - 1 dan tanggung renteng, dan nasabah wajib mengikuti HALMI untuk membayar angsuran yang telah ditentukan oleh lembaga. Modal pinjmanan pembiayaan qard hanya sebesar Rp. 1.000 .000 sampai 1.500.000, pinjaman yang diberikan hanya sedikit karena resikonya sangat besar pula apabila terjadi sesuatu diluar dugaan karena pembiayaan qard ini tanpa agunan atau jaminan.

Berdasarkan Analisis implementasi pembiayaan qard di Bank Wakaf Mikro Al Fitrah Wava Mandiri Surabaya di atas sesuai dengan Fatwa DSN MUI No 19 Tahun 2001. Adapun dampak dari pembiayaan qard di Bank Wakaf Al Fitrah Wava Mandiri Surabaya yaitu peningkatan pendapatan dan peningkatan usaha nasabah. Adapun kendala yang dihadapi nasabah adalah pemberian modal pinjaman yang jumlahnya sangat kecil, sehingga ada pengaruh negatif dalam pengembangan usaha nasabah.

\section{Daftar Pustaka}

Ahmad asy-Syarbasyi.al-Mu'jam allesmawati-Iqtisad al-Islami. Beirut: Dar Alamil Kutub, 1987.

Ascarya.Akad dan Produk Bank Syariah.jakarta: Rajagrafindo Persada, 2008.

Burhan Bungin.Metodologi Penelitian Sosial Format-Format Kuantitaf dan Kualitatif.Surabaya: Airlangga University press, 2001.

Departemen Agama Republik Indonesia.Pedoman Pengelolaan dan Pengembangan Wakaf.Jakarta: Ditjen Bimas Islam dan Penyelenggara Haji Proyek Peningkatan Pemberdayaan Wakaf,2004.

Departemen Agama Republik Indonesia.Strategi Pengembangan Wakaf Tunai di Indonesia. Jakarta: Direktor Pemberdayaan Wakaf,2007.

Dewan Syariah Nasional- Majelis Ulama Indonesia, National Sharia Board Indonesian Council of Ulama .Jakarta : Fatwa DSN MUI, 2014.

Fatwa DSN MUI No 19 Tahun 2001.

Kebijakan Manajemen Organisasi LKM Syariah Bank Wakaf Mikro, 2018. 